\title{
STEADY STATE AND STABILITY ANALYSIS OF RESPIRATORY CONTROL SYSTEM USING LABVIEW
}

\author{
${ }^{1}$ P Srinivas ${ }^{2}$ P.Durga Prasada Rao \\ ${ }^{1}$ Associate Professor, Department of EIE, VR Siddhartha Engineering College, \\ Vijayawada, India \\ Email: paruchuris_99@yahoo.com \\ ${ }^{2}$ Assistant Professor, Department of EIE, VR Siddhartha Engineering College, \\ Vijayawada, India \\ Email: dprasad_ie@yahoo.com
}

\begin{abstract}
The human respiratory system is a well developed and complex system which is constantly being perturbed by physiologic disturbances. Engineering performed good support in modeling and simulation of the various functional systems of the human body. The modeling of respiratory of the human body is required to understand its operation and pathologies present. This paper describes a steady state model and cheyne stokes breathing model of respiratory control system. Both models are simulated in LabVIEW. The steady state model gives steady state values of $\mathrm{O}_{2}$ and $\mathrm{CO}_{2}$ at sea level and high altitudes which are useful to provide sufficient ventilation to the persons at high altitudes and also used to analyze the stability of normal persons and congestive heart failure persons at high altitudes from cheyne stokes breathing model.
\end{abstract}

\section{KEYWORDS}

Ventilation, modeling, Gas exchanger, chemoreceptor, Respiratory controller, cheyne stokes, LabVIEW

\section{INTRODUCTION}

Respiratory system is a highly specific physiological sub system which is the exchange of gases $\mathrm{O}_{2}$ and $\mathrm{CO}_{2}$ through the act of breathing. The behavior of this system is defined by the continual interaction of the controller and peripheral processes which is similar to closed loop system. The respiratory system is well defined with peripheral controlled processes and central controller, based on the empirical analysis the respiratory control system. The engineers can be design and develop mathematical models of human body that is done through simulation software which is validated by medical specialists [1]. The behavior of the respiratory when a flow of air inside called inhalation and the movement of gas determine the mechanics of ventilation. This is very helpful for diagnosis and prediction of chronic diseases. The model used in this work is analyzed the steady state condition of human at sea level and high altitude cases, with these results, we developed a proposal which are useful for control the ventilation. This level of design for intensive care ventilators and special ventilators used in chronic care units. Generally, the respiratory control system is modeled as a closed loop feedback/feed forward regulator. 


\section{ANATOMY OF RESPIRATORY TRACT}

The respiratory system with upper respiratory tract includes the nose, nasal cavity, ethmoidal air cells, fronal sinuses, maxillary sinus, sphenoidal sinus, larynx and trachea. The lower tract of respiratory system consists of lungs, air ways (bronchi and bronchioles) and air sacs (alveoli). In this, the right lung is divided in to three sections, called lobes and similarly the left lung is divided in to two lobes. The passage of air from atmosphere to lungs is given below.

Initially the air enters in to the body through the nose or mouth and travels down to the throat through larynx and trachea. Then it enters in the lungs through main stem bronchi which is available in both left and right lungs. In the lungs, these main stem bronchi divided in to smaller bronchi and again divided in to smaller tubes called bronchioles. These bronchioles end with tiny air sacs called alveoli. There are several millions of alveoli in each lung, and these areas which are responsible for gas exchange. Each alveolus is closely interacted with a capillary network which contains deoxygenated blood from the pulmonary artery [2].

Basically the lung diseases are obstructive and restrictive types. In obstructive lung diseases, the person may feel hard to exhale all the air in the lungs. In case of restrictive lung diseases, the person has difficulty to fully expand their lungs with air. The most general causes of obstructive lung diseases are cystic fibrosis, asthma, bronchiectasis and chronic obstructive pulmonary disease (COPD) [3]. In restrictive lung disease occurred due to several conditions like obesity, neuromuscular disease and interstitial lung disease, etc.

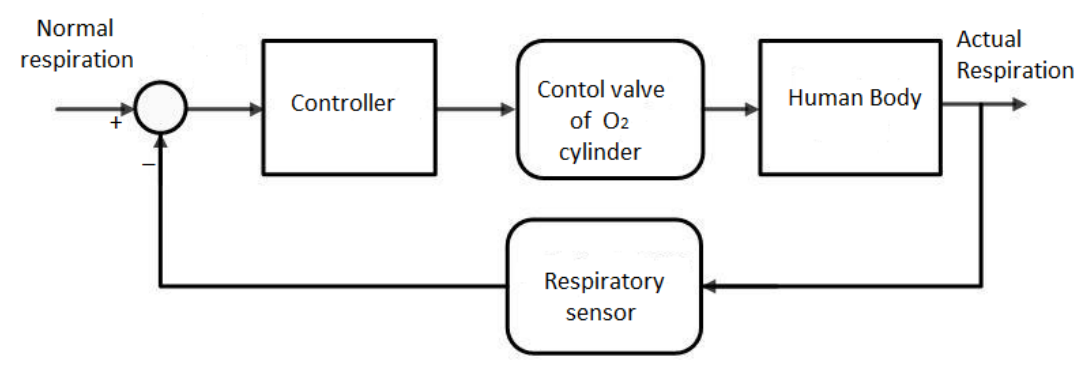

Figure 1: Closed Loop Control

So far, we have discussed the diseases related to lungs and we developed an automatic closed loop control as shown in Fig.1. This is useful in mountain trekkers and sea divers for automatic opening /closing of the oxygen cylinder valve. The oxygen is the process variable which is to be maintained based on the need of the human body. Here, the respiratory output from the human body is sensed by the respiratory sensor which is fed to the controller. Based on the error the controller facilitates the required amount of oxygen to the lungs. Initially, we developed a model for controller later; we simulated the entire model of entire closed loop respiratory closed loop systems in lab view. The simulation results are stored in the look up table and based on the error, the controller produces desired output for proper functioning of control valve. Based on the superiority of the lab view over all other simulink tools, we have chosen the lab view for this application. The modeling of the respiratory system is given clearly in the next section.

\section{MODELING}

The $\mathrm{PaCO} 2$ is measured by arterial blood gases. Partial pressure means to the pressure exerted by a specific gas ion a mixture of other gases. Then, Paco2 simply shows the measurement of $\mathrm{CO} 2$ 
in arterial blood. A rise in $\mathrm{PaCO} 2$ by $1 \mathrm{~mm}$ of $\mathrm{Hg}$ may increase the ventilator output by a third of its resting level. However, at high altitude during inhalation of a gas mixture containing low $\mathrm{O} 2$ content, even normal person needs additional drive to breathe due to hypoxia. Generally if the $\mathrm{PaO} 2$ value is less than the $70 \mathrm{~mm}$ of $\mathrm{Hg}$ then healthy person may also get hypoxia. The normal range for $\mathrm{PaCO} 2$ is 35 to $45 \mathrm{~mm}$ of $\mathrm{Hg}$. If $\mathrm{PaCO} 2$ of person is more than $45 \mathrm{~mm}$ of $\mathrm{Hg}$, then ha has more $\mathrm{CO} 2$ in his blood. This is called "hypercapnia". In normal steady state condition metabolic consumption rate of both $\mathrm{O} 2$ and $\mathrm{CO} 2$ are constant. Suppose if the ventilation is drastically increased, then it leads to increase in the partial pressure of $\mathrm{O} 2$ and decrease in the partial pressure of $\mathrm{CO} 2$ which in turn lower ventilation. Therefore, negative feedback is employed for the chemical plant. The respiratory control system used for modeling is shown in figure 2 which consists of chemical plant, mechanical plant, Respiratory control pattern generator and chemoreceptor [4][5].

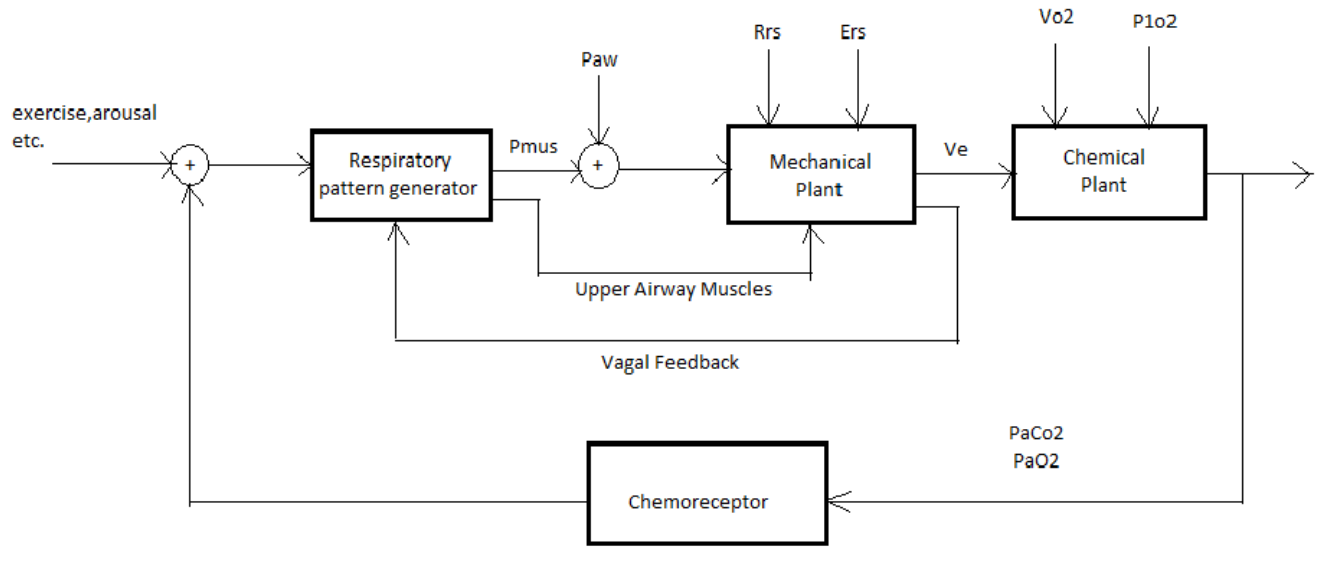

Figure 2: Respiratory control system

The input output relationships of the chemical plant are affected by the various disturbances. For example, increase in the metabolic production of $\mathrm{CO} 2$ due to muscular exercise. The added $\mathrm{CO} 2$ in the lungs is eliminated by an increase in pulmonary ventilation, the control action in restoring $\mathrm{PaCO} 2$ varies considerably with the type of disturbance. The sensitivity of the chemical plant depends on the load of metabolic $\mathrm{CO} 2$ in the lungs. The removal of $\mathrm{CO} 2$ from the lungs is further decreased because of perfusion mal distribution in case of pulmonary disease patients. On the other hand, metabolic acidosis and alkalosis alters arterial blood gas tensions and $\mathrm{pH}$ through acid- base buffering in blood. All these disturbances affect the chemical plant and leads to non linearity of the plant. The major job of the controller is to control the $V_{E}$ irrespective of the disturbances with respiratory system.

Chemoreceptor consists of peripheral and central chemo receptors which are modeled by a linear first order dynamics. Peripheral receptors are having shorter response time constant and delay than central chemo receptors. The rapid changes in the blood chemistry are gated through these chemo receptors.

In mechanical plant the respiratory muscles may serve as respiratory pump. They may also act to reduce ventilation and the mechanical efficiency of respiratory muscles depends on the forcevelocity and force-length relationships. The respiratory pump consists different actuators to regulate $\mathrm{V}_{\mathrm{F}}$ in the face of many disturbances which are originating in the lungs, thorax and airways [6] [7].

The main job of respiration is to meet the metabolic demand by the exchange of $\mathrm{O} 2$ and $\mathrm{CO} 2$.The simplest controller model is a proportional controller. In the chemo reflex loop, the control signal 
is a fixed relay which regulates the Ve. The stability analysis is done to a linearized system. If the loop gain and phase shift exceed unity and 180 degrees respectively then system goes to instability. The proposed model in this paper gives satisfactory responses for respiratory system. Analysis of closed loop control of ventilation and chemical plant is done through chemo reflex model in efficient manner [8].

\subsection{THE MODEL FOR GAS EXCHANGER}

In chemical plant, the gas exchange occurs in the lungs. From the mass balance equations of $\mathrm{O} 2$ and $\mathrm{CO} 2$, the operating characteristics of gas exchanger are obtained. The $\mathrm{VCO} 2$ is the metabolic $\mathrm{CO} 2$ production rate. The $\mathrm{VCO} 2$ indicates that the rate at which $\mathrm{CO} 2$ delivered in to the lungs is equal to the metabolic production rate. The net flow of $\mathrm{CO} 2$ is later equal to the difference in volumetric fractions of $\mathrm{CO} 2$ in the air entering and leaving the alveoli is multiplied by $\mathrm{V}_{\mathrm{A}}$. Here, some portion of $\mathrm{V}_{\mathrm{E}}$ is actually participated in the gas exchange process and some portion of total ventilation " $\mathrm{V}_{\mathrm{D}}$ ".

$V_{A}=V_{E}-V_{D}$

and the $\mathrm{CO}_{2}$ mass balance:

$V_{\mathrm{CO} 2}=k V_{A}\left(F_{\mathrm{ACO} 2}-F_{\mathrm{ICO} 2}\right)$

Now the constant ' $k$ ' can be is expressed as

$$
k=\frac{\mathrm{Pb}-47}{863}
$$

The volumetric fractions $\mathrm{F}_{\mathrm{ACO} 2}, \mathrm{~F}_{\mathrm{ICO} 2}$ can be represented as partial pressures using Daltons law

$$
\begin{aligned}
& P_{I C O 2}=F_{I C O 2}\left(P_{b}-47\right) \\
& P_{A C o 2}=F_{A C O 2}\left(P_{b}-47\right)
\end{aligned}
$$

From (2),(3),(4),(5) we get

$$
P_{\mathrm{ACO} 2}=P_{I C O 2}+\frac{863 \mathrm{Vc}}{\mathrm{Va}}
$$

Similarly developing mass balance equation for $\mathrm{O}_{2}$

$$
P_{A O 2}=P_{I o 2}-\frac{863 \mathrm{Vc}}{\mathrm{Va}}
$$

Here, $\mathrm{P}_{\mathrm{ACO} 2}$ - Partial pressure of alveolar $\mathrm{O} 2$

$\mathrm{P}_{\mathrm{AO} 2}$ - Partial pressure of alveolar $\mathrm{CO} 2$

$\mathrm{P}_{\mathrm{ICO} 2}$-Partial pressure of inhaled $\mathrm{CO} 2$ 


\section{$\mathrm{P}_{\mathrm{IO} 2}$-Partial pressure of inhaled O2}

Some portion of $\mathrm{V}_{\mathrm{A}}$ is shared in both (6) and (7) equations, $\mathrm{CO} 2$ and $\mathrm{O} 2$ are independent.

\subsection{THE MODEL FOR THE RESPIRATORY CONTROLLER}

In the feedback section of respiratory control system shown in Fig.2 consists of chemo receptors for controlling. The generation of respiratory rhythm is dependent on the lower brain's neuronal circuits. In the gas exchange process, $\mathrm{O} 2$ and $\mathrm{CO} 2$ are independent but in case of controlling both are closely interacted. The ventilator controller output is represented as sum of the $\mathrm{O}_{2}$ independent term and a term in which there is a multiplicative interaction between hypoxia and hypercapnia.

$$
\left.\begin{array}{cc}
V c=\left(1.46+\frac{32}{\mathrm{P}_{\mathrm{ao} 2}-38.6}\right)\left(\mathrm{P}_{\mathrm{aco} 2}-37\right) & \mathrm{P}_{\mathrm{aco} 2}>37 \\
0 & \mathrm{P}_{\mathrm{aco} 2} \leq 37
\end{array}\right\}
$$

\subsection{MODEL FOR CHEYNE -STOKES BREATHING}

The term periodic breathing has a high importance in chronic heart failure patient's diagnosis with poor ventricular function. Periodic breathing is clusters of breaths which are separated by apnea. Cheyne stokes respiration is an abnormal breathing pattern i.e. faster breathing followed by slower breathing, in between temporary cessation in breathing.

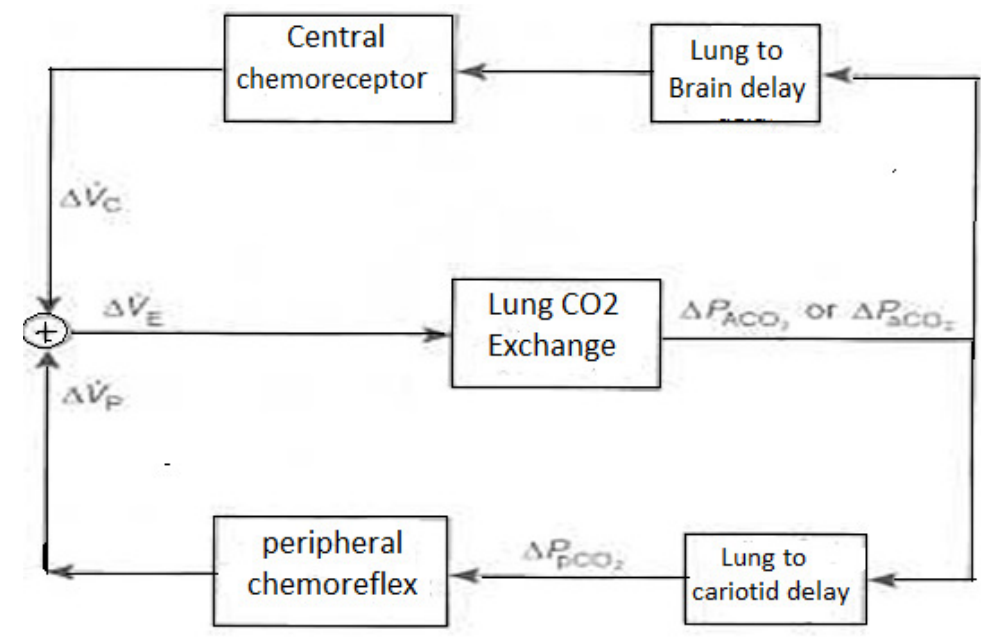

Figure 3: Respiratory control system including transportation delays

Periodic breathing does not occur commonly in normal people during wakefulness. This is characterized by periodic breathing results from instability in the feedback control system which controls the ventilation and arterial blood gases. The response of the peripheral chemo receptors is faster than the central chemo receptors. In this model we conveniently assume there are functionally two feedback loops, one from central chemo reflex and the other one from peripheral chemo reflex. First we modeled this system without transport delays and finally we added transport delays and taken the loop transfer function for stability analysis. A simplified schematic 
International Journal of Control Theory and Computer Modelling (IJCTCM) Vol.2, No.6, November 2012

as shown in figure. 3 which consists of delays taken to transport blood from the lungs and chemo receptors [9].

\section{MODELING OF THE LUNGS}

The dynamic equivalent of the gas exchange equation is given below

$\mathrm{V}_{\mathrm{L}}\left(\mathrm{dP}_{\mathrm{ACO} 2} / \mathrm{dt}\right)=\left(\mathrm{V}_{\mathrm{E}^{-}} \mathrm{V}_{\mathrm{D}}\right)\left(\mathrm{P}_{\mathrm{ICO} 2^{-}} \mathrm{P}_{\mathrm{ACO} 2}\right)+863 \mathrm{Q}\left(\mathrm{C}_{\mathrm{VCO}^{-}}-\mathrm{C}_{\mathrm{aco} 2}\right)$

Where

$\mathrm{Q}=$ Pulmonary blood flow

$\mathrm{V}_{\mathrm{L}} \quad=$ Effective $\mathrm{CO} 2$ storage capacity of the lungs

$\mathrm{C}_{\mathrm{VCO} 2}=$ Concentrations in arterial and

$\mathrm{CaCO}=$ Mixed venous blood

$\mathrm{V}_{\mathrm{L}}=\left(\mathrm{d}\left(\Delta \mathrm{P}_{\mathrm{ACO} 2}\right) / \mathrm{dt}\right)=\left(\mathrm{V}_{\mathrm{E}^{-}} \mathrm{V}_{\mathrm{D}}\right) \Delta \mathrm{P}_{\mathrm{ACO} 2}+\left(\mathrm{P}_{\mathrm{ICO} 2}-\mathrm{P}_{\mathrm{ACO} 2}\right) \Delta \mathrm{V}_{\mathrm{E}}-863 \mathrm{Q} \Delta \mathrm{C}_{\mathrm{aco} 2}$

$\mathrm{V}_{\mathrm{L}}\left(\mathrm{d}\left(\Delta \mathrm{P}_{\mathrm{aCO} 2}\right) / \mathrm{dt}\right)+\left(\mathrm{V}_{\mathrm{E}}-\mathrm{V}_{\mathrm{D}}+863 \mathrm{Q} \mathrm{K}_{\mathrm{CO} 2}\right) \Delta \mathrm{P}_{\mathrm{Aco} 2}=\left(\mathrm{PICO} 2-\mathrm{P}_{\mathrm{aco} 2}\right) \Delta \mathrm{V}_{\mathrm{E}}$

Taking Laplace Transforms To Equation (5.4.3)

$\mathrm{H}_{\mathrm{L}}(\mathrm{s})=\left(\Delta \mathrm{P}_{\mathrm{aco} 2} / \Delta \mathrm{V}_{\mathrm{E}}\right)=\left(-\mathrm{G}_{\mathrm{IL}} /(\mathrm{TL} . \mathrm{s}+1)\right)$

Where

$$
\begin{aligned}
& \mathrm{T}_{\mathrm{L}}=\mathrm{V}_{\text {lung }} /\left(\mathrm{V}_{\mathrm{E}}-\mathrm{V}_{\mathrm{D}}+863 \mathrm{QK} \mathrm{K}_{\mathrm{CO} 2}\right) \\
& \mathrm{G}_{\mathrm{L}}=\left(\mathrm{P}_{\mathrm{aCO} 2}-\mathrm{P}_{\mathrm{ICO} 2}\right) /\left(\mathrm{V}_{\mathrm{E}} \mathrm{V}_{\mathrm{D}}+863 \mathrm{QK} \mathrm{K}_{\mathrm{CO} 2}\right)
\end{aligned}
$$

\section{TRANSPORT DELAYS}

We assume that pulmonary end-capillary blood returning to the heart will take some time $\left(\mathrm{T}_{\mathrm{p}}\right)$ to arrive at the peripheral chemoreceptor's and a longer time $\left(T_{c>} T_{p}\right)$. Thus,

$\Delta \mathrm{P}_{\mathrm{pCO} 2}(\mathrm{t})=\Delta \mathrm{P}_{\mathrm{aco} 2}\left(\mathrm{t}-\mathrm{T}_{\mathrm{p}}\right)$

$\Delta \mathrm{P}_{\mathrm{cCO} 2}(\mathrm{t})=\Delta \mathrm{P}_{\mathrm{aco} 2}\left(\mathrm{t}-\mathrm{T}_{\mathrm{c}}\right)$

Applying Laplace to the Above Equations,

we get $\Delta \mathrm{P}_{\mathrm{pCO} 2}(\mathrm{~s})=\mathrm{e}^{-\mathrm{s} T \mathrm{p}} \Delta \mathrm{P}_{\mathrm{aco} 2}(\mathrm{~s})$

$\Delta \mathrm{P}_{\mathrm{cCO} 2}(\mathrm{~s})=\mathrm{e}^{-\mathrm{sTp}} \Delta \mathrm{P}_{\mathrm{aco} 2}(\mathrm{~s})$

Dynamic response of peripheral and central chemo receptors are

$\mathrm{T}_{\mathrm{p}}(\mathrm{dV} \mathrm{p} / \mathrm{dt})+\mathrm{V}_{\mathrm{P}}=\mathrm{G}_{\mathrm{p}}\left[\mathrm{P}_{\mathrm{pCO} 2}-\mathrm{I}_{\mathrm{p}}\right]$ 
$\mathrm{T}_{\mathrm{c}}(\mathrm{dV} \mathrm{c} / \mathrm{dt})+\mathrm{V}_{\mathrm{c}}=\mathrm{G}_{\mathrm{c}}\left[\mathrm{P}_{\mathrm{cCO} 2}-\mathrm{I}_{\mathrm{c}}\right]$

Applying Laplace Transforms for Equations

$\Delta \mathrm{V}_{\mathrm{p}}(\mathrm{s})=\left(\mathrm{G}_{\mathrm{p}} /\left(\mathrm{T}_{\mathrm{p}} \mathrm{s}+1\right)\right) \Delta \mathrm{P}_{\mathrm{pco2}}(\mathrm{s})$

$\Delta \mathrm{V}_{\mathrm{c}}(\mathrm{s})=\left(\mathrm{G}_{\mathrm{c}} /\left(\mathrm{T}_{\mathrm{c}} \mathrm{s}+1\right)\right) \Delta \mathrm{P}_{\mathrm{c} \text { co2 }}(\mathrm{s})$

The loop transfer functions of Lung mechanics with transportation delays are

$\mathrm{H}_{\mathrm{Lp}}(\mathrm{s})=\left(\Delta \mathrm{V}_{\mathrm{p}}(\mathrm{s}) / \Delta \mathrm{V}_{\mathrm{E}}(\mathrm{s})\right)=\left(\mathrm{G}_{\text {lung }} \mathrm{G}_{\mathrm{p}} \cdot \mathrm{e}^{-\mathrm{s} T \mathrm{p}}\right) /\left(\mathrm{T}_{\mathrm{L}} \mathrm{s}+1\right)\left(\mathrm{T}_{\mathrm{p}} \mathrm{s}+1\right)$

$\mathrm{H}_{\mathrm{Lc}}(\mathrm{s})=\left(\Delta \mathrm{V}_{\mathrm{c}}(\mathrm{s}) / \Delta \mathrm{V}_{\mathrm{E}}(\mathrm{s})\right)=\left(\mathrm{G}_{\text {lung }} \mathrm{G}_{\mathrm{p}} \cdot \mathrm{e}^{-\mathrm{s} \mathrm{T} \mathrm{p}}\right) /\left(\mathrm{T}_{\mathrm{L}} \mathrm{s}+1\right)\left(\mathrm{T}_{\mathrm{c}} \mathrm{s}+1\right)$

Overall Frequency Response of the Loop Transfer Function is

$\mathrm{H}_{\mathrm{L}}(\omega)=\left(\Delta \mathrm{V}_{\mathrm{p}}(\omega)+\Delta \mathrm{V}_{\mathrm{c}}(\omega)\right) /\left(\Delta \mathrm{V}_{\mathrm{E}}(\omega)\right)$

$H_{L}(\omega)=\left(G_{L} /\left(1+j \omega T_{L}\right)\right)\left(\left(G_{p} \cdot e^{-j \omega T p} / 1+j \omega T_{p}\right)+\left(G_{c} \cdot e^{-j \omega T p} / 1+j \omega T_{c}\right)\right.$

The Stability analysis of lung mechanics for normal and congestive heart failure persons are tested by applying Nyquist stability Criterion.

\section{SIMULATION RESULTS}

\subsection{STEADY STATE MODEL}

The steady state model in LABVIEW is implemented and the simulation results are shown in Figures (4), (5),(6) and (7). Equation (8) becomes progressively less valid as $\mathrm{P}_{\mathrm{ao} 2}$ approaches the asymptotic value 38.6 as controller output becomes infinitely large. Here case (1) corresponds to the controller output at normal sea level shown in figures (4) and (5). In case (2) gives the output of a controller in high altitude (8500 ft) is shown in figures (6) and (7). 


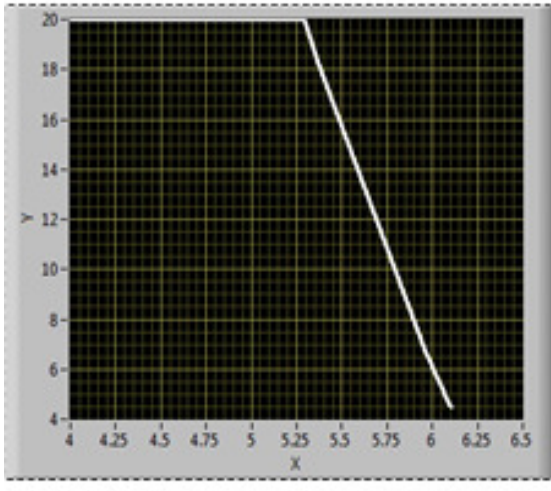

Figure 4: $\mathrm{V}_{E}$ in vs $\mathrm{V}_{E}$ out in case (1)

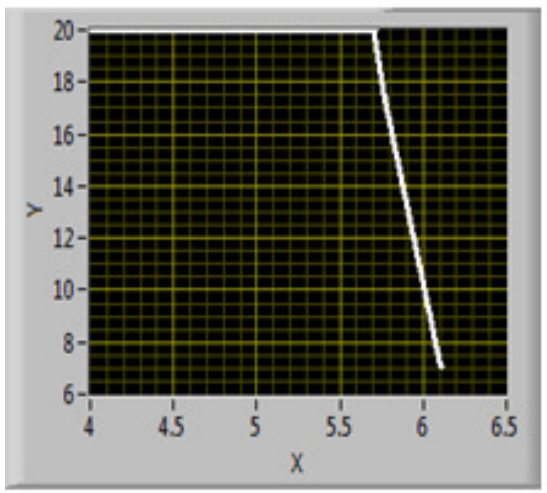

Figure $6: \mathrm{V}_{\mathrm{E}}$ in vs $\mathrm{V}_{\text {Fout }}$ in case (2)

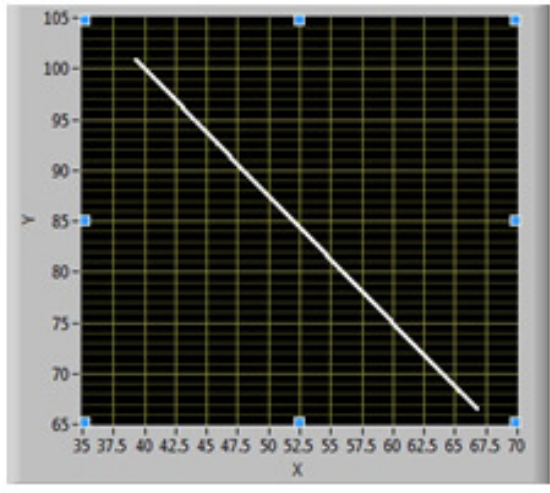

Figure 5: $\mathrm{P}_{\mathrm{aco}}$ vs $\mathrm{P}_{\mathrm{ab} 2}$ in case (1)

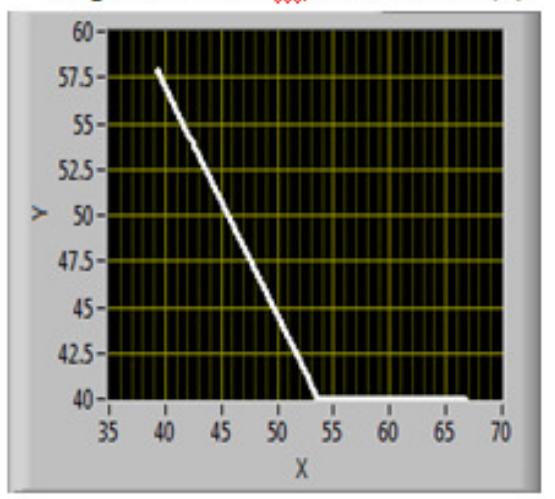

Figure 7: $P_{\mathrm{aco2}}$ vs $P_{\mathrm{a} 02}$ in case (2)

We assumed that in case (1) the person is at ground level. So the $\mathrm{P}_{\mathrm{IO} 2}$ value is set equal to $150 \mathrm{~mm}$ of $\mathrm{Hg}$ i.e. $21 \%$ of room air, while $\mathrm{P}_{\mathrm{ICO} 2}$ is set equal to zero. The value of $\mathrm{V}_{\mathrm{E}}$ affects the partial pressures of $\mathrm{O} 2$ and $\mathrm{CO} 2$. At low value of $\mathrm{V}_{\mathrm{E}}$, the $\mathrm{P}_{\mathrm{AO} 2}$ is $65 \mathrm{~mm}$ of $\mathrm{Hg}$ and $\mathrm{P}_{\mathrm{ACO} 2}$ is 67 $\mathrm{mm}$ of $\mathrm{Hg}$. The simulation is terminated when $\mathrm{V}_{\mathrm{E}}=6 \mathrm{~L} / \mathrm{min}$ then $\mathrm{P}_{\mathrm{ACO} 2}=40 \mathrm{~mm}$ of $\mathrm{Hg}$ and $\mathrm{P}_{\mathrm{AO}_{2}}=100 \mathrm{~mm}$ of $\mathrm{Hg}$. The values are tabulated below in table (1) and (2). Based on $\mathrm{V}_{\mathrm{E}}$ value $\mathrm{P}_{\mathrm{ACO} 2}$ and $\mathrm{P}_{\mathrm{AO} 2}$ are effected i.e, if $\mathrm{V}_{\mathrm{E}}$ increases, $\mathrm{P}_{\mathrm{ACO} 2}$ decreases and $\mathrm{P}_{\mathrm{AO} 2}$ increases.

In case (2) we consider that if the person is at high altitude (8500ft) [10]. So the $\mathrm{P}_{\mathrm{IO} 2}$ value is set equal to $107 \mathrm{~mm}$ of $\mathrm{Hg}$ i.e. $15 \%$ of room air, while $\mathrm{P}_{\mathrm{ICO} 2}$ is set equal to zero. Initially due low value of $\mathrm{V}_{\mathrm{E}}, \mathrm{P}_{\mathrm{AO} 2}$ is $40 \mathrm{~mm}$ of $\mathrm{Hg}$ and $\mathrm{P}_{\mathrm{ACO} 2}$ is $67 \mathrm{~mm}$ of $\mathrm{Hg}$. However due to the effect of the saturation block, $\mathrm{P}_{\mathrm{AO} 2}$, is not allowed to fall below 40. The simulation is terminated when $\mathrm{V}_{\mathrm{E}}=6.1$ $\mathrm{L} / \mathrm{min}$ then $\mathrm{P}_{\mathrm{ACO} 2}=39 \mathrm{~mm}$ of $\mathrm{Hg}$ and $\mathrm{P}_{\mathrm{AO} 2}=58.2 \mathrm{~mm}$ of $\mathrm{Hg}$. The $\mathrm{P}_{\mathrm{ACO} 2 \text { and }} \mathrm{P}_{\mathrm{AO} 2}$ for $\mathrm{V}_{\mathrm{E}}$ case (1) and case (2) given below in tables (3) and (4).

\subsection{CHEYNE- STOKES BREATHING MODEL}

Cheyne- stokes breathing model is implemented based on steady state value of $\mathrm{P}_{\mathrm{ACO} 2}$ obtained from steady state model and the parameters of respiratory system(shown in table 5) for normal and congestive heart failure persons. 
International Journal of Control Theory and Computer Modelling (IJCTCM) Vol.2, No.6, November 2012

Table5: parameter values used in Cheyne-stokes breathing Model.

Table 1: $\mathrm{P}_{\mathrm{ACO} 2}$ vS $\mathrm{P}_{\mathrm{AO} 2}$ in case 1

\begin{tabular}{|c|c|}
\hline $\begin{array}{c}\mathrm{P}_{\mathrm{ACO2}} \text { in mm } \\
\text { of } \mathrm{Hg}\end{array}$ & $\begin{array}{c}\mathrm{P}_{\mathrm{A02}} \text { in } \mathrm{mmn} \\
\text { of } \mathrm{Hg}\end{array}$ \\
\hline 67 & 65 \\
\hline 60 & 70 \\
\hline 50 & 80 \\
\hline 40 & 100 \\
\hline
\end{tabular}

Table3: $\mathrm{P}_{\mathrm{AO2}}$ vs $\mathrm{P}_{\mathrm{AcO}}$ in case 2

\begin{tabular}{|c|c|}
\hline $\begin{array}{c}\mathrm{P}_{\mathrm{AO2}} \text { in } \mathrm{mm} \\
\text { of } \mathrm{Hg}\end{array}$ & $\begin{array}{c}\mathrm{P}_{\mathrm{Aco} 2} \text { in } \mathrm{mm} \\
\text { of } \mathrm{Hg}\end{array}$ \\
\hline 40 & 67 \\
\hline 40 & 60 \\
\hline 45 & 52 \\
\hline 58.2 & 39 \\
\hline
\end{tabular}

Table2: $V_{\mathrm{E}}$ in $\mathrm{vs} \mathrm{V}_{\mathrm{E}}$ out in case 1

\begin{tabular}{|c|c|}
\hline $\mathrm{V}_{\mathrm{E}}$ in & $\mathrm{V}_{\mathrm{E}}$ out \\
\hline 5.1 & 20 \\
\hline 5.4 & 15 \\
\hline 5.8 & 10 \\
\hline 6 & 6 \\
\hline
\end{tabular}

Table4: $V_{\mathrm{E}}$ in $v S \mathrm{~V}_{\mathrm{E}}$ out in case 2

\begin{tabular}{|c|c|}
\hline$V_{E}$ if & $V_{\text {E out }}$ \\
\hline 5.1 & 20 \\
\hline 5.4 & 15 \\
\hline 5.8 & 10 \\
\hline 6.1 & 6.1 \\
\hline
\end{tabular}

\begin{tabular}{|c|l|}
\hline Parameter & \multicolumn{1}{|c|}{ Value } \\
\hline $\mathrm{V}_{\mathrm{L}}$ & $2.5 \mathrm{~L}$ \\
$\mathrm{~K}_{\mathrm{eoz}}$ & $0.0065 \mathrm{mmHg}^{-1}$ \\
$\mathrm{G}_{\mathrm{p}}$ & $0.02 \mathrm{Ls}^{-1} \mathrm{mmHg}$ \\
$\mathrm{G}_{\mathrm{c}}$ & $0.04 \mathrm{Ls}^{-1} \mathrm{mmHg}^{-1}$ \\
$\mathrm{~T}_{\mathrm{p}}$ & $205 e \mathrm{c}$ \\
$\mathrm{T}_{\mathrm{c}}$ & $120 \mathrm{sec}$ \\
$\mathrm{V}_{\mathrm{E}}$ & $0.12 \mathrm{Ls}^{-1}$ \\
$\mathrm{~V}_{\mathrm{D}}$ & $0.03 \mathrm{Ls}^{-1}$ \\
$\mathrm{~T}_{\mathrm{P}}$ & $6.1 \mathrm{sec}$ \\
\hline
\end{tabular}

Nyquist plots for normal and congestive heart failure persons at high altitudes based on Cheyne-stokes breathing model are shown in figures(8) and(9). 


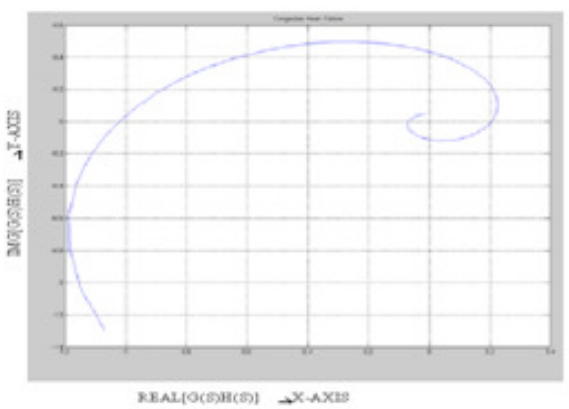

Figure 8: Normal Person

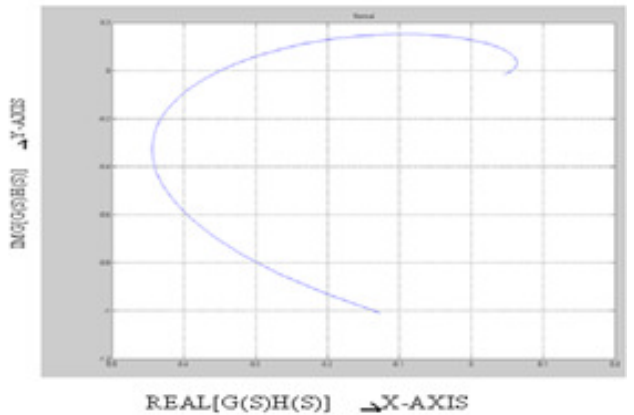

Figure 9: congestive heart failure Person

The nyquist plot shown in figures(8) and (9) represent a bandwidth of frequencies range given 0.01 to $0.1 \mathrm{~Hz}$ i.e. inter breath periodicities of cycle duration $10 \mathrm{Sec}$ to $100 \mathrm{Sec}$. In the case of normal person (shown in fig.) respiratory system is stable with $\mathrm{G}_{\mathrm{C}}=0.34$ which occurred at $\mathrm{f}=0.0295 \mathrm{~Hz}$ and having a periodicity of $34 \mathrm{Sec}$. In the case of congestive heart failure Person the respiratory system is less stable and also enters into unstable region if the frequency oscillations are more than critical frequency and the loop gain is 1.02 at critical frequency of $\mathrm{f}=0.0165 \mathrm{~Hz}$ and periodicity of $61 \mathrm{Sec}$ These oscillations are consistent throughout the total cycle duration for normal and congestive heart failure case.

\section{CONCLUSION}

The steady state model demonstrates quite clearly the negative feedback nature of respiratory control. If the person is moving to high altitude levels then the oxygen content decreases and there is a need for inhale more air. These kinds of problems can be overcome by the simulated model of respiratory control system which is developed through Lab view. In this system the controller job is to calculate the steady state values of $\mathrm{P}_{\mathrm{ACO} 2}$ and $\mathrm{P}_{\mathrm{AO} 2}$. The values are entered into look up tables and controller can be developed to control the inhalation of oxygen. By implementing this control action we can reduce the wastage of the oxygen in $\mathrm{O}_{2}$ cylinders and we can avoid the manual control. Cheynestokes breathing model demonstrates the stability of the respiratory system for normal and congestive heart failure persons at high altitudes. The stability analysis gives prior information about the critical breathing frequencies of patients which is helpful in various diagnoses related to respiratory system.

The performance of this respiratory control system using lab view is satisfied based on the simulation results and this can also employ for some medical applications like designing an automatic ventilator for patients.

\section{REFERENCES}

[1] Cumming ham, D.J.C, Integrative aspects of regulation of breathing: A personal view. In: MTP International Review of Science:L Physiology series one, vol.2, Respiratory Physiology, University Park Press, Baltimore, 1974;pp. 303-369.

[2] J.Freedman H. Lehmann, R. McCormick, M. Wachter, "Respiratory Physiology”. Johns Hopkins School of Medicine, USA, 1996.

[3] C.S.Poon, "Respiratory Models and Controls," in Biomedical Engineering Handbook, 2nd ed. vol. 3, Joseph D. Bronzino, Ed. CRCPress, 1995.

[4] Khoo, M.C.k., R.E.Kronauer,K.P.Strohland A.S.Slutsky. Factors inducing periodic breathing in humans: a general model.j.Appl.Physiol. 53:644-659, 1982. 
International Journal of Control Theory and Computer Modelling (IJCTCM) Vol.2, No.6, November 2012

[5] B.Diong,H.Nazeran,P.Nava,M.Goldman, "Modeling Human Respiratory Impedance. Comparing the Best Method with the Least Estimation Errors". IEEE Engineering In Medicine And Biology Magazine, January/February 2007

[6] Bruce EN. 1996. Temporal variations in the pattern of breathing. J Appl Physiolgy 80:1079.

[7] Balis UJ, Morris KF, Koleski J, et al. 1994. Simulations of a ventrolateral medullary neural network for respiratory rhythmogenesis inferred from spike train cross-correlation. Biol Cybern 70:311.

[8] Defares JG. 1964. Principles of feedback control and their application to the respiratory control system.In WO Fenn, H Rahn (eds), Handbook of Physiology, Respiration, sec 3, vol 1, pp 649_ 680,Washington, DC, American Physiological Society.

[9] NS Cherniack, JG Widdicombe (eds), Handbook of Physiology, sec 3, The Respiratory System, vol 2, Control of Breathing, part 2, pp 93-134, Washington, DC, American Physiological Society

[10] Fitzgerald RS, Lahiri S. 1986. Reflex responses to chemoreceptor stimulation. In NS Cherniack, JG Widdicombe (eds), Handbook of Physiology, sec 3, The Respiratory System, vol 2, Control of Breathing, part 1, pp 313-362, Washington, DC, American Physiological Society

\section{Appendix}

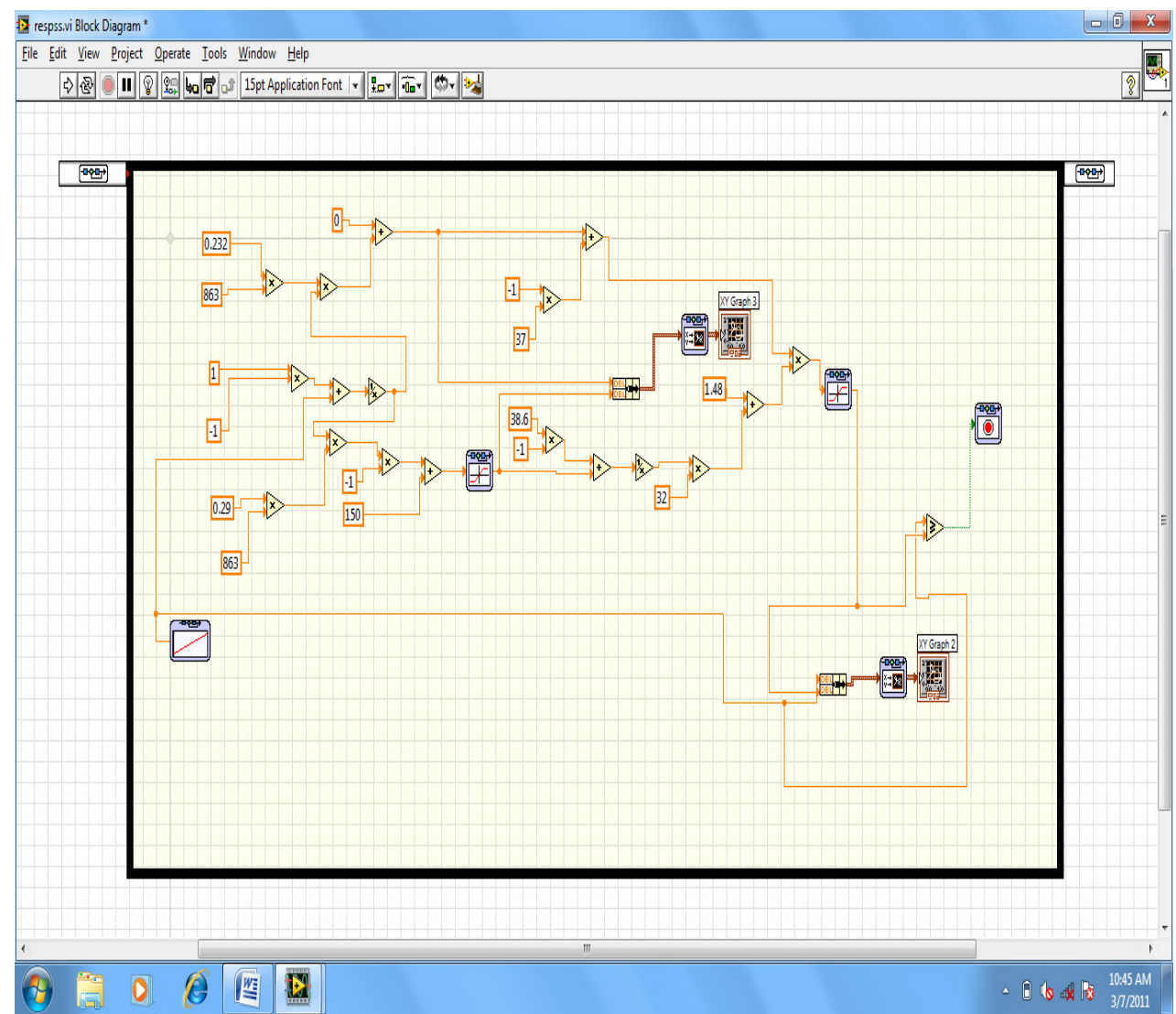

Figure4: LabVIEW Simulation for Steady state model 